Egypt. J. of Nutrition and Health Vol. 14 No. 2 July (2019)

\title{
Curative and hepatoprotective action of fenugreek (Trigonellafoenumgaraecum) seeds against cisplatin induced oxidative liver damage in male albino rats
}

\author{
Wesam M. Abd-Elrahman \\ Nutrition and Food Science Department, Faculty of Home Economics \\ Al-Azhar University, Egypt.
}

\begin{abstract}
Fenugreek is one of several herbal medicines whose seeds and leaves are used either as food or as drink. The present study was designed to investigate possible potential hepatocurative \& hepatoprotective activity of $5 \%$ and $10 \%$ of fenugreek (Trigonellafoenumgaraecum) seeds against cisplatin $(5 \mathrm{mg} / \mathrm{kg}$ body wt.) induced oxidative liver damage in male albino rats. The experimental protocol designed as the animals(42 rats) were divided into seven groups including both curative and protective groups (six rats each) : Group (1) Negative control group was fed on basal diet only for 28 days and curative groups including subgroups $(2,3,4)$ were injected interaperitoneal by cisplatin $(5 \mathrm{mg} / \mathrm{kg}$ body wt.) from the first day and waiting for 24 hours to induce hepatotoxicity as follows: curative Positive control group (subgroup 2) was fed on basal diet after injection, subgroup $(3,4)$ was fed basal diet $+5 \%$ and $10 \%$ fenugreek seeds powder respectively after injection by cisplatin. While Protective groups including subgroups $(5,6,7)$, they were injected with cisplatin interaperitoneal on the last day of the experiment and kept 24 hours after injection and divided as follows : protective Positive control group (subgroup 5) was fed basal diet and given cisplatin interaperitoneal injection $(5 \mathrm{mg} / \mathrm{kg}$ body wt.) on the last day of experiment. Subgroups (6) and (7) were fed basal diet and given fenugreek seeds $5 \%$ and $10 \%$ respectively and they were injected with cisplatin interaperitoneal on the last day of the experiment, then all rats were fasted overnight (12 hours), sacrificed and blood samples were collected to determine chemical analysis (AST, ALT, ALP, total protein, albumin, globulin, Albumin/Globulin, MDA, SOD, CAT. Besides, nutritional and biological parameters were recorded (FI, BWG\%, FER). The results showed that fenugreek seeds powder at $5 \%$ and $10 \%$ intake in curative and protective groups improved feed intake, the body weight gain, feed efficiency ratio, liver function, and antioxidant enzymes compared with positive control groups (injected with cisplatin). It can be concluded that fenugreek seed improved the activities of liver functions and antioxidant enzymes against cisplatin that induced oxidative liver injury.
\end{abstract}

Key words: fenugreek seeds, cisplatin (CIS), oxidative liver injuiry, male albino rats

\section{Introduction}

Fenugreek (Trigonella foenum graecum Linn) is an annual herb that belongs to the family Leguminosae. The seeds of fenugreek are commonly used in the Middle East and South Asia as a spice in food preparation and used as traditional medicines in diabetes, highcholesterol, inflammations (ALMashhadani, 2017). Fenugreek, like other legumes, is a good source of dietary protein (about 24\%), fatty acids (5-10\%) which include linoleic, linolenic, oleic and palmatic. It has $45-65 \%$ total carbohydrates with $15 \%$ of galactomannose (soluble fiber) and other active compounds required in a human body such as saponins, coumarin and fenugreekine( Eidi et al., 2007). 


\section{Wesam M. Abd-Elrahman}

Fenugreek was found to treat glucose and lipid homeostasis in several metabolic disorders (Raju and Bird, 2006). The seeds have been shown to possess hypoglycemic action(Srinivasan, 2005 andGad, et al., 2006). Furthermore, fenugreek seed extract was found to decrease plasma triglycerides (Handa, 2005) and to reduce triglycerides accumulation in the liver (Raju and Bird, 2006). It was reported, also, that fenugreek seed polyphenols had a positive influence on both lipid profile and on quantitative and qualitative properties of collagen in hepatotoxicity (Kaviarasan, et al., 2007 and Dixit, et al., 2005).Furthermore, fenugreek was shown to possess antioxidant activity, and to afford protection against cancer of the breast (Amin, et al., 2005) and colon (Raju, et al., 2004).

The liver plays a major role in transforming and clearing chemicals which lead to increase its susceptibility to the toxicity from these agents (Abu-Raghif, et al., 2016). Liver diseases are one of the major causes of mortality and morbidity worldwide (Abboud and Kaplowitz, 2007). Drugs are an important cause of liver injury, more than 900 drugs, toxins, and herbs have been reported to cause hepatic injury. Cisplatin [cis-diamminechloroplatinum (II)] is a potent antineoplastic agent used for the treatment of a wide range of cancers (Abu-Raghif, et al., 2016). Nevertheless, this drug has severe toxic effects that interfere with its therapeutic efficacy, namely nephrotoxicity and hepatotoxicity. Although the nephrotoxicity of cisplatin has been recognized as the most important dose-limiting factor, little is known about cisplatin induced liver injury. Hepatotoxicity is not considered as a dose limiting toxicity for cisplatin, but liver toxicity can occur when the antineoplastic drug is administered at high doses (Ziccaet al., 2002).Oxidative stress is one of the most important mechanisms involved in cisplatin induced toxicity. The mitochondrion is the primary target for cisplatin induced oxidative stress, resulting in loss of mitochondrial protein- $\mathrm{SH}$, inhibition of calcium uptake and a reduction in the mitochondrial membrane potential (Saadet al, 2004).

This study has been carried out to evaluate possible advantage that could be obtained by using fenugreek seed powder as curative or protective effect against cisplatin-induced liver damage in male albino rats.

\section{Material and methods}

\section{Materials:}

1) Fenugreek seeds (Trigonellafoenumgaraecum) were purchased from Field Crops Research Institute, Agricultural Research Center, Giza- Egypt.

2) Casein, vitamins, minerals, cellulose and choline chloride were obtained from Morgan Company for chemical laboratory, Cairo, Egypt.

3) Normal male albino rats (Sprague Dawley Strain) weighing $(150 \pm 10 \mathrm{~g})$ were obtained from vaccine and immunity organization Helwan Farm, Cairo, Egypt.

4) Cisplatin was obtained from the Cairo Company for Chemical Trading, Cairo, Egypt.

\section{Methods:}

Preparation of fenugreek seeds:

Fenugreek seeds were washed dried and crushed using electric blender to a fine powder which was packed in air-tight plastic bags till use for basal diet supplementation.

\section{Chemical composition of fenugreek:}

Chemical composition of fenugreek (moisture, ash, crude protein, and fat) were determined according to the methods of the AOAC (2010). While total carbohydrates were estimated by difference from initial weight of the sample as follows: - Carbohydrates $\%=100 \%-(\%$ moisture $+\%$ protein $+\%$ fat $+\%$ ash $)$. 


\section{Egypt. J. of Nutrition and Health Vol. 14 No. 2 July (2019)}

Phenolic compounds of fenugreek

The polyphenol compounds in fenugreek seeds powder was fractionated and identified for phenolic compounds and flavonoids compounds by HPLC, according to the method described by Tarolaet al., (2013).

\section{Experimental design:}

A total of 42 rats were housed in well- aerated cages under hygienic condition and fed on basal diet for one week for adaptation. After this week, rats were divided into seven groups including both curative and protective groups (six rats each).

I - Group (1) was kept as negative control group and was fed on basal diet only according to Reeves et al., (1993)during the whole period of the experiment(28 days).

The other thirty six rats were divided into two main groups (18 rats for each main group). The II Secand main group (18 rats) were injected interaperitoneal with Cisplatin $(5 \mathrm{mg} / \mathrm{kg}$ body wt.)once only in the first day of the experimental period and kept as curative groups according to Yogeshet al., (2010), then on the next day it was divided into three subgroups as follows:

2- subgroup (2) was considered as control positive (curative)and was fed on basal diet

3- $\quad$ subgroup (3) was fed on basal diet $+5 \%$ fenugreek seeds powder replacing equivalent amount from the basal diet

4- $\quad$ subgroup (4) was fed on basal diet $+10 \%$ fenugreek seeds powder replacing equivalent amount from the basal diet

The III Third main group (18 rats) weredivided into three subgroups as follows:

5- $\quad$ subgroup (5) was considered as control positive (protective) and it was fed on basal diet

6- $\quad$ subgroup (6) was fed on basal diet $+5 \%$ fenugreek seeds powderreplacing equivalent amount from the basal diet

7- $\quad$ subgroup (7) was fed on basal diet $+10 \%$ fenugreek seeds powder replacing equivalent amount from the basal diet

Subgroups $(5,6,7)$ were in Jected interaperitoneal with cisplatin( $5 \mathrm{mg} / \mathrm{kg}$ body wt.) and kept for 24 hours after injection.

Feed intake (Fl), body weight gain (BWG) and feed efficiency ratio (FER) were determined according to Chapman et al. (1959). At the end of experimental period, all rats were fasted overnight (12 hours), sacrificed and the blood samples were collected and centrifuged to obtain the serum which was kept frozen till analysis. Livers were collected after being removal, cleaned in saline solution, dried by filter paper and weighted, and rapidly taken on ice bags and frozen at $-18^{\circ} \mathrm{C}$, untill used for assessment of lipid peroxidation and antioxidant activity in liver tissue.

Biochemical analysis of serum:

Aspartate aminotransferase (AST) and alanine aminotransferase (ALT) were determined according to Bergmeyeret al., (1986), albumin according to Drupt, (1974), total protein according to Sonnenwirthand Jaret (1980). Globulin and albumin/ globulin(A/G) were calculated according to Busher, (1990)using the following equation:

Globulin = total protein - albumin

Assessment of Oxidant/Antioxidant Activity in liver:

After defrosting livers were homogenized and centrifuged at $10,000 \mathrm{rpm}$ at $0^{\circ} \mathrm{C}$ for $20 \mathrm{~min}$. the supernatant part was used for estimation of different antioxidant level by calorimetric method using spectrophotometer (Merck thermo spectronic, Model NO. UV-1, double beam), Lipid peroxidation by thiobarbuturic acidreactive substances (TBARS) methods (Uchiyama and Mihara 1978), Superoxide dismutase (SOD) by 


\section{Wesam M. Abd-Elrahman}

the method developed by Misra and Fridovich, (1972) and Catalase (CAT) by colorimetric assay (Sinha, 1972).

Statistical analysis:

Results are expressed as mean \pm SD. Data were statistically analyzed using one-way analysis of variance "ANOVA" according to Armitage\& Berry, (1987).Computer software system SPSS (version 15).

\section{Result and discussion}

\section{Chemical composition offenugreek seeds}

Fenugreek was analyzed for chemical composition (moisture, protein, carbohydrates, fat, crude fiber and ash). The obtained results showed in table (1) on the dry weight basis. The results showed that the crude protein, total carbohydrates, fat content, crude fiber and ash were 27.16, 46.3, 3.12, 10.82 and $4.20 \%$ on dry weight, respectively. The present results are in agreement with Mehrafarinet al., (2010) who concluded that fenugreek seed contains $45-60 \%$ carbohydrates, mainly mucilaginous fiber (galactomannans), 20-30\% proteins, 5 - 10\% fixed oils (lipids). Also our data are in agreement with Meghwal and Goswami, (2012) and Mullaicharamet al., (2013) and Khorshidianet al., (2016). On the other hand our results disagreed with El-Bairi et al., (2017) who reported that fenugreek contains 23-26\% protein, $6-7 \%$ fat and $58 \%$ carbohydrates of which about $25 \%$ is dietary fiber.

Table (1)

\begin{tabular}{l|l} 
Chemical composition of dry fenugreek seeds powder (g/100gm) \\
\hline Compositions & $\mathrm{gm} / 100 \mathrm{gm}$ \\
\hline Moisture & 8.4 \\
\hline Protein & 27.16 \\
\hline Carbohydrate & 46.3 \\
\hline Fat & 3.12 \\
\hline Crude Fiber & 10.82 \\
\hline Ash & 4.20 \\
\hline
\end{tabular}

\section{Phenolic compounds of fenugreek seeds}

Fenugreek seeds analyzed for their phenolic compounds are shown in table (2). The present results are in agreement with Akbari,et al., (2012) who showed that,numbers of important phenolic and styrylic acid derivatives, such as p-coumaric acid, caffeic acid, chlorogenic acid, coumarin derivatives, namely hymecromone, trigoforin, trigocoumarin, scopoletin, and cyclooctane derivatives, such as schizandrin , were isolated from different parts of fenugreek plant. 
Egypt. J. of Nutrition and Health Vol. 14 No. 2 July (2019)

Table (2)

Phenolic compounds of fenugreek $(\mu \mathrm{g} / \mathrm{g})$.

\begin{tabular}{l|l}
\hline Phenolic compounds & $(\mu \mathrm{g} / \mathrm{g})$ \\
\hline Gallic acid & 319.46 \\
\hline Chromogenic acid & 80.79 \\
\hline Catechin & 72.08 \\
\hline Methyl gallate & 51.53 \\
\hline Coffeic acid & 38.37 \\
\hline Syringic acid & 322.01 \\
\hline Pyro catechol & 18.20 \\
\hline Rutin & 56.62 \\
\hline Ellagic acid & 957.32 \\
\hline Coumaric acid & 593.78 \\
\hline Vanillin & 858.36 \\
\hline Ferulic acid & 94.76 \\
\hline Naringenin & 64.15 \\
\hline Taxifolin & 40.89 \\
\hline Cinnamic acid & 4.74 \\
\hline Kaempferol & 35.64 \\
\hline
\end{tabular}

Nutritional parameters of the biological experiment:

Food intake, body weight gain, and feed efficiency ratio were determined and the results are tabulated in Table (3).

- It could be observed that there are no significant difference between (-ve) control and the curative groups in food intake (FI) while there are significant increase between (-ve) control and protective groups except (subgroup 7) .

- $\quad$ Results of final body weight showed significant decrease in curative subgroups $(2,3,4)$ when compared to normal rats (group 1) $(17.11 \pm 1.21 \mathrm{a}, 17.08 \pm .43 \mathrm{a}$ and $17.33 \pm .72 \mathrm{a}$ respectively) while Protective subgroups $(6,7)$ showed significant increase $(P<0.05)$ compared with normal rats (group 1$)$.

- $\quad$ The results in the table 3 showed significant decrease in feed efficiency ratio was observed at positive controls (subgroups 2 and 5 ) groups compared to negative group $\left(1.10 \pm .10^{\mathrm{a}}\right.$ and $1.16 \pm .08^{\mathrm{a}}, 1.35$ $\pm .17^{\mathrm{b}}$ respectively). The best results were protective fenugreek subgroups ( 6 and7). 
Wesam M. Abd-EIrahman

Table (3)

Effect of fenugreek seeds on food intake (FI), body weight gain (BWG) and feed efficiency ratio (FER) in both curative and protective groups of rats

\begin{tabular}{|c|c|c|c|c|c|}
\hline \multicolumn{3}{|c|}{ Parameters } & $\begin{array}{l}\text { FI } \\
\text { (g/day) }\end{array}$ & $\begin{array}{l}\text { BWG } \\
\text { (g) }\end{array}$ & (FER) \\
\hline \multicolumn{3}{|c|}{ Groups } & Mean \pm SD & Mean \pm SD & Mean \pm SD \\
\hline $\mathrm{I}$ & \multicolumn{2}{|c|}{ Group (1) (-ve) Control } & $14.48 \pm .80^{\mathrm{a}}$ & $19.46 \pm 1.75^{b}$ & $1.35 \pm .17^{b}$ \\
\hline \multirow{3}{*}{ II } & \multirow{3}{*}{$\begin{array}{l}\text { Curative } \\
\text { groups }\end{array}$} & subgroup (2) & $15.86 \pm .54^{\mathrm{ab}}$ & $17.11 \pm 1.21^{a}$ & $1.10 \pm .10^{a}$ \\
\hline & & subgroup (3) & $15.96 \pm .48^{\mathrm{ab}}$ & $17.08 \pm .43^{a}$ & $1.15 \pm .08^{a}$ \\
\hline & & subgroup (4) & $14.86 \pm .54^{\mathrm{a}}$ & $17.33 \pm .72^{\mathrm{a}}$ & $1.30 \pm .08^{b}$ \\
\hline \multirow{3}{*}{ III } & \multirow{3}{*}{$\begin{array}{l}\text { Protective } \\
\text { groups }\end{array}$} & subgroup (5) & $16.95 \pm .47^{b}$ & $19.80 \pm 1.02^{b}$ & $1.16 \pm .08^{a}$ \\
\hline & & subgroup (6) & $17.23 \pm .32^{b}$ & $22.53 \pm .59^{c}$ & $1.33 \pm .05^{b}$ \\
\hline & & subgroup (7) & $15.83 \pm .42^{\mathrm{ab}}$ & $24.81 \pm 1.55^{\mathrm{d}}$ & $1.40 \pm .12^{b}$ \\
\hline
\end{tabular}

-Values denote arithmetic means \pm SD of the mean. Means with different letters $(a, b, c, d, e, f)$ in the same column differ significantly at $(p \geq 0.05)$ while those with similar letters are non-significant.

- Group (1): negative control group, subgroup (2): curative positive group, subgroup (3): curative fenugreek $5 \%$, subgroup (4): curative fenugreek 10\%, subgroup (5): protective positive group, subgroup (6): protective fenugreek $5 \%$, subgroup (7): protective fenugreek $10 \%$

konopelnyuket al., (2015) illustrated two possible mechanisms of fenugreek decreasing the total body weight. Fenugreek flushes out the carbohydrates from the body before they enter the blood stream resulting in weight loss. Fenugreek seeds contain a high proportion of soluble fiber. This fiber forms a gelatinous structure which may have effects on slowing the digestion and absorption of food from the intestine and creates a sense of fullness in the abdomen, thus suppresses appetite and promotes weight loss.

\section{Effect of fenugreek seeds on liver functions in the curative and protective groups}

Liver enzymes of different experimental groups are reported in Table (4). Exposing rats to cisplatin showed significant $(P<0.05)$ increase in the level of liver enzymes (AST, ALT and ALP) in curative and protective (+ve control groups) (subgroups 2 and 5 ). While feeding rats on fenugreek $5 \%$ significantly decreased the levels of liver enzymes in both treated and protective groups. 
Egypt. J. of Nutrition and Health Vol. 14 No. 2 July (2019)

Table (4)

Effect of fenugreek seeds Group on serum (AST, ALT and ALP) levels in both curative and protective groups of rats

\begin{tabular}{|c|c|c|c|c|c|}
\hline \multicolumn{3}{|c|}{ Parameters } & $\begin{array}{l}\text { AST } \\
(\mathrm{IU} / \mathrm{L})\end{array}$ & $\begin{array}{l}\text { ALT } \\
\text { (IU/L) }\end{array}$ & $\begin{array}{l}\text { ALP } \\
(\mathrm{IU} / \mathrm{L})\end{array}$ \\
\hline \multicolumn{3}{|c|}{ Groups } & Mean \pm SD & Mean \pm SD & Mean \pm SD \\
\hline I & \multicolumn{2}{|c|}{ Group (1) (-ve) Control } & $43.66 \pm 4.32^{a}$ & $27.00 \pm 2.00^{\mathrm{a}}$ & $138.16 \pm 4.79^{b}$ \\
\hline \multirow{3}{*}{ II } & \multirow{3}{*}{$\begin{array}{l}\text { Curative } \\
\text { groups }\end{array}$} & subgroup (2) & $142.00 \pm 3.74^{\top}$ & $47.66 \pm 3.72^{c}$ & $185.50 \pm 4.46^{\dagger}$ \\
\hline & & subgroup (3) & $86.16 \pm 4.49^{\mathrm{C}}$ & $38.16 \pm 2.22^{b}$ & $172.66 \pm 4.08^{\mathrm{e}}$ \\
\hline & & subgroup (4) & $80.50 \pm 3.93^{b}$ & $38.33 \pm 3.26^{b}$ & $124.33 \pm 5.60^{\mathrm{a}}$ \\
\hline & \multirow{3}{*}{$\begin{array}{l}\text { Protective } \\
\text { groups }\end{array}$} & subgroup (5) & $155.33 \pm 4.54^{9}$ & $155.66 \pm 4.50^{\mathrm{e}}$ & $148.66 \pm 5.35^{\mathrm{a}}$ \\
\hline & & subgroup (6) & $134.00 \pm 3.52^{\mathrm{e}}$ & $114.83 \pm 4.30^{\mathrm{d}}$ & $144.33 \pm 5.12^{\mathrm{cd}}$ \\
\hline & & subgroup (7) & $125.16 \pm 4.70^{c}$ & $29.83 \pm 3.81^{\mathrm{a}}$ & $139.33 \pm 4.08^{\mathrm{bC}}$ \\
\hline
\end{tabular}

- Values denote arithmetic means \pm SD of the mean. Means with different letters $(a, b, c, d, e, f)$ in the same column differ significantly at $(p \geq 0.05)$ while those with similar letters are non-significant.

- Group (1): negative control group, subgroup (2): curative positive group, subgroup (3): curative fenugreek $5 \%$, subgroup (4): curative fenugreek $10 \%$, subgroup (5): protective positive group, subgroup (6): protective fenugreek $5 \%$, subgroup (7): protective fenugreek $10 \%$

Cisplatin-induces nephrotoxicity through multiple mechanisms, including hypoxia, the generation of free radicals, inflammation, and apoptosis with an increase in the pro-apoptotic protein bax and a decrease in the anti-apoptotic protein Bcl-2 (Tsuruyaet al., 2003).While the mechanisms of cisplatininduced hepatotoxicity are not fully understood (Hong et al., 2005), the link between oxidative stress and cisplatin toxicity was suggested in many experimental models (Bentliet al., 2013 \& Lu and Cederbaum, 2006).

Our results showed that feeding fenugreek can prevent cisplatin induced toxicity in the liver by significantly reduction of AST, ALT, ALP, these results are in agreement with (Meeraet al., 2009)and (ALMashhadani, 2017), they achieved that the normalization of the above enzyme levels in rat liver with the plant drugs estabilishes the hepato protective effect of $\mathrm{T}$. foenum-graecum which may be able to induce accelerated regeneration of liver cells reducing the leakage of these enzymes into the blood. The results indicated that fenugreek significantly prevented the increased liver function marker enzyme activity induced by cisplatin, indicating an improvement of the functional status of the liver by the fenugreek.

\section{Effect of fenugreek seeds on serum protein, albumin, globulin and albumin/globulin in the curative and protective groups (table 5)}

The table shows the effect of supplemented fenugreek on total protein, albumin, globulin and albumin/globulin compared with negative control groups. Cisplatin administration $(5 \mathrm{mg} / \mathrm{kg})$ resulted in significant increase in total protein and albumin compared with the negative control groupe. Treatment with fenugreek $5 \%$ (subgroup 3) resulted in a significant reduction in serum level of total protein and albumin compare to curative positive group (subgroup 2). There were no significant difference among protective groups and normal rats group in total protein and albumin. There were no significant difference among normal rats group (group 1) compared with curative groups in globulin and $A / G$ while positive protective group (subgroup 5) show significant decrease in globulin compare with negative group ( group 1). 
Wesam M. Abd-EIrahman

Table (5)

Effect of fenugreek seeds on total protein, albumin, globulin in both curative and protective groups of rats

\begin{tabular}{|c|c|c|c|c|c|c|}
\hline \multicolumn{3}{|c|}{ Parameters } & $\begin{array}{c}\text { Total protein } \\
(\mathrm{gm} / \mathrm{dl})\end{array}$ & $\begin{array}{l}\text { albumin } \\
\text { (gm/dl) }\end{array}$ & $\begin{array}{l}\text { Globulin } \\
\text { (gm/dl) }\end{array}$ & $\mathrm{A} / \mathrm{G}$ \\
\hline \multicolumn{2}{|c|}{ Groups } & & Mean \pm SD & Mean \pm SD & Mean \pm SD & Mean \pm SD \\
\hline$\overline{\mathrm{I}}$ & \multicolumn{2}{|c|}{ Group (1) (-ve) Control } & $3.11 \pm .11^{\mathrm{abc}}$ & $2.46 \pm .18^{\mathrm{bc}}$ & $.65 \pm .24^{\mathrm{b}}$ & $4.45 \pm 2.43^{\mathrm{b}}$ \\
\hline \multirow{3}{*}{ II } & \multirow{3}{*}{$\begin{array}{l}\text { Curative } \\
\text { groups }\end{array}$} & subgroup (2) & $3.48 \pm .07^{\mathrm{d}}$ & $2.73 \pm .18^{\mathrm{d}}$ & $.75 \pm .20^{b}$ & $3.90 \pm 1.26^{\mathrm{ab}}$ \\
\hline & & subgroup (3) & $3.00 \pm .26^{\mathrm{ab}}$ & $2.36 \pm .22^{\mathrm{ab}}$ & $.66 \pm .22^{b}$ & $4.06 \pm 2.06^{\mathrm{ab}}$ \\
\hline & & subgroup (4) & $3.53 \pm .33^{\mathrm{d}}$ & $2.63 \pm .05^{\mathrm{cd}}$ & $.90 \pm .35^{b}$ & $3.43 \pm 1.96^{\text {ab }}$ \\
\hline \multirow{3}{*}{ III } & \multirow{3}{*}{$\begin{array}{l}\text { Protective } \\
\text { groups }\end{array}$} & subgroup (5) & $2.83 \pm .36^{\mathrm{ab}}$ & $2.31 \pm .14^{\text {ab }}$ & $.35 \pm .08^{\mathrm{a}}$ & $6.9 \pm 2.08^{\mathrm{C}}$ \\
\hline & & subgroup (6) & $3.25 \pm .27^{\mathrm{bcd}}$ & $2.43 \pm .31^{\mathrm{bc}}$ & $.81 \pm .03^{b}$ & $3.3 \pm 1.11^{\mathrm{ab}}$ \\
\hline & & subgroup (7) & $3.38 \pm .14^{\mathrm{cd}}$ & $2.36 \pm .05^{\text {ab }}$ & $1.2 \pm .16^{\mathrm{C}}$ & $1.8 \pm .30^{\mathrm{a}}$ \\
\hline
\end{tabular}

-Values denote arithmetic means \pm SD of the mean. Means with different letters $(a, b, c, d, e, f)$ in the same column differ significantly at $(p \geq 0.05)$ while those with similar letters are non-significant.

- Group (1): negative control group, subgroup (2): curative positive group, subgroup (3): curative fenugreek $5 \%$, subgroup (4): curative fenugreek $10 \%$, subgroup (5): protective positive group, subgroup (6): protective fenugreek $5 \%$, subgroup (7): protective fenugreek $10 \%$

\section{Effect of feeding fenugreek seedson SOD, CAT and lipid peroxide MDA in the curative and protective groups of rats (table 6)}

The table illustrated the activity of liver superoxide dismutase (SOD)and catalase (CAT) which were significantly increased in treatment fenugreek subgroups $(3,4)$ when compared with subgroup (2) (+ve control) .while protective groups showed significant increase in protective fenugreek subgroups $(6,7)$ when compared with subgroup (5). Table (6) also showed a significant decrease in liver malondialdehyde (MDA) in both positive subgroups (2 and 5) when compared with normal rat (group 1).other treated and protective groups showed significant decrease compared with the positive groups.

Table (6)

Effect of fenugreek seeds on antioxidant enzymes (SOD, CAT) and lipid peroxide MDA) in both curative and protective groups of rats

\begin{tabular}{|c|c|c|c|c|c|}
\hline \multirow{2}{*}{\multicolumn{3}{|c|}{ Groups }} & $\begin{array}{l}\mathrm{MDA} \\
\mathrm{Nmol} / \mathrm{mg}\end{array}$ & $\begin{array}{l}\mathrm{SOD} \\
\mathrm{Ng} / \mathrm{mg}\end{array}$ & $\begin{array}{l}\text { CAT } \\
\mathrm{U} / \mathrm{l}\end{array}$ \\
\hline & & & Mean \pm S.D & Mean \pm SD & Mean \pm SD \\
\hline $\mathrm{I}$ & \multicolumn{2}{|c|}{ Group (1) (-ve) Control } & $.16 \pm .05^{\mathrm{a}}$ & $.21 \pm .04^{\mathrm{de}}$ & $.21 \pm .029^{\dagger}$ \\
\hline \multirow{3}{*}{ II } & \multirow{3}{*}{$\begin{array}{l}\text { Curative } \\
\text { groups }\end{array}$} & subgroup (2) & $.41 \pm .10^{b}$ & $.12 \pm .03^{\mathrm{ab}}$ & $.11 \pm .005^{\mathrm{a}}$ \\
\hline & & subgroup (3) & $.13 \pm .01^{a}$ & $.22 \pm .02^{\mathrm{e}}$ & $.17 \pm .009^{\mathrm{de}}$ \\
\hline & & subgroup (4) & $.13 \pm .03^{a}$ & $.19 \pm .01^{\mathrm{d}}$ & $.19 \pm .034^{\mathrm{ef}}$ \\
\hline \multirow{3}{*}{ III } & \multirow{3}{*}{$\begin{array}{l}\text { Protective } \\
\text { groups }\end{array}$} & subgroup (5) & $.39 \pm .01^{b}$ & $.09 \pm .01^{a}$ & $.12 \pm .018^{\mathrm{ab}}$ \\
\hline & & subgroup (6) & $.13 \pm .03^{a}$ & $.14 \pm .01^{\mathrm{bc}}$ & $.14 \pm .028^{\mathrm{bc}}$ \\
\hline & & subgroup (7) & $.11 \pm .02^{a}$ & $.15 \pm .01^{\mathrm{c}}$ & $.16 \pm .010^{\mathrm{cd}}$ \\
\hline
\end{tabular}

-Values denote arithmetic means \pm SD of the mean. Means with different letters $(a, b, c, d, e, f)$ in the same column differ significantly at $(p \geq 0.05)$ while those with similar letters are non-significant. 


\section{Egypt. J. of Nutrition and Health Vol. 14 No. 2 July (2019)}

- Group (1): negative control group, subgroup (2): curative positive group, subgroup (3): curative fenugreek $5 \%$, subgroup (4): curative fenugreek 10\%, subgroup (5): protective positive group, subgroup (6): protective fenugreek $5 \%$, subgroup (7): protective fenugreek $10 \%$

Several reports have implicated free radicals and reactive oxygen species (ROS) in cisplatin toxicity associated with an increase in lipid peroxidation (LPO), decreased levels of protein bound sulfhydryl groups and glutathione (Pratibhaet al., 2006).

Cisplatin is a potent anticancer agents that cause a wide range of adverse effects and organ toxicity including hepatotoxicity, nephrotoxicity and vascular endothelial dysfunction that mediated by different mechanisms such as inflammation and oxidative stress (Siddik, 2003). Cisplatin-induced hepatotoxicity is a major problem in the cancer therapy (Wang and Stephen, 2005). It has been reported that cisplatin induced hepatotoxicity is closely associated with an increase in lipid peroxidation manifested by increased MDA (Eidet al., 2016). Inflammation plays an important role in cisplatin induced liver injury (Athiraet al., 2016). Although the precise inflammatory mechanisms are unknown, marked attenuation of cisplatin induced liver damage by inhibition of tumor necrosis factor alpha (TNF- $\alpha$ ) indicates that TNF- $\alpha$ has a central role of mediation cisplatin induced liver injury (Li et al., 2016).

\section{Conclusion}

In conclusion, the present work showed the curative and protective effects of fenugreek seeds against cisplatin-induced hepatic injury in rats at both levels of supplementation of fenugreek (5\%, $10 \%)$.

\section{References}

Abboud, G. and Kaplowitz, N. ( 2007):

Drug induced liver injury. Drug Safety. 30, P.277-294.

Akbari, M., Rasouli, H. and Bahdor, T. (2012):

Physiological and pharmaceutical effect of fenugreek: a review. Journal of Pharmacy; 2(4):49-53.

AL-Mashhadani, F.A. (2017):

Effect of Fenugreek Seed and Leaves on Some Hematological and Biochemical Parameters in CCl4-induced Liver Injury.Int.J.Curr.Microbiol.App.Sci., 6(4): 2328-2337.

Amin, A., Al-Kaabi, A., Al-Falasi, S. and Daoud, S. (2005):

Chemopreventive activities of Trigonella foenum graecum (Fenugreek) against breast cancer.Cell Biol Int., 29 (8): 687.

AOAC., (2010):

Official Methods of Analysis of Association of Official Chemists. $18^{\text {th }}$ Ed., Washington, D.C., USA.

Armitage, P. and Berry,G. (1987):

Statistical methods in medical research. Boston,MA:Blackwell Scientific. 559 p.

Athira, K.V., Madhana, R.M., Kasala, E.R., Samudrala, P.K., Lahkar, M., Gogoi, R.(2016): 


\section{Wesam M. Abd-EIrahman}

Morin Hydrate Mitigates Cisplatin-Induced Renal and Hepatic Injury by Impeding Oxidative/Nitrosative Stress and Inflammation in mice. Journal of Biochemical and Molecular Toxicology, 30 (12): 571-579.

Bentli, R., Parlakpinar, H., Polat, A., Samdanci, E., Sarihan, M.E. and Sagir, M. (2013):

Molsidomine prevents cisplatin-induced hepatotoxicity. Archives of medical research. 44(7):521-8.

Bergmeyer, H.U., Horder, M. and Rey, J. (1986):

Approved recommendation on IFCC methods for the measurement of catalytic enzymes. Part 3: IFCC method for alanine aminotransferase. J. Clin. Chem. Clin. Biochem. 1986b;24:481495.

Busher, J.T. (1990):

Serum albumin and globulin.clinical methods: the history, physical and laboratory examinations. $3^{\text {rd }}$ edition. Boston. Chapter: 101.

Chapman, D.G., Gastilla, R. and Campbell, T.A. (1959):

Evaluation of protein in food. I. A. Method for the determination of protein efficiency ratio. Can.J. Biochem. Physio. 1(37) 679-686

Dixit, P, Ghaskadbi, S., Mohan, H. and Devasagayam T. P. (2005):

Antioxidant properties of germinated fenugreek seed.Phytother.Res. 19 (11): 977.

Drupt, F. (1974):

Colorimetric method for determination of albumin. Pharm. Biol., 9: 777-779.

Eid , A.H., Abdelkader , N.F., Abd El-Raouf , O.M., Fawzy , H.M. and El-Denshary , E.S. (2016):

Carvedilol alleviates testicular and spermatological damage induced by cisplatin in rats via modulation of oxidative stress and inflammation.Arch Pharm Res. 39:1693-1702.

Eidi, A., Eidi, M. and Sokhteh, M. (2007):

Effect of Fenugreek (Trigonella foenum graecum L.) seeds on serum parameters in normal and streptozotocin-induced diabetic rats.Nutr. Res., 728-733.

El-Bairi, K., Ouzir, M., Agnieszka, N.andKhalki, L. (2017):

Anticancer potential of Trigonella foenum graecum: cellular and molecular targets. Biomed.Pharmacother; 90:479-491.

Friedman, S.E., Grendell, J.H. andMcQuaid , K.R. (2003):

Current diagnosis \& treatment in gastroenterology, Lang Medical Books/McGraw-Hill, New York, 664-679.

Gad, M.Z., El-Sawalhi, M.M., Ismail, M.F. and El-Tanbouly, N.D. (2006):

Biochemical study of the anti-diabetic action of the Egyptian plants Fenugreek and Balanites. Molecular and Cellular Biochemistry, 281 (1-2): 173.

Handa, T., Yamaguchi, K. and Sonoy, Y.K. (2005): 
Egypt. J. of Nutrition and Health Vol. 14 No. 2 July (2019)

Effect of fenugreek seed extract in obese mice fed a high-fat diet. Biosci.Biotechnol.Biochem.,69(6): 1186.

Hong, K.O., Hwang, J.K., Park, K.K. and Kim, S.H. (2005):

Phosphorylation of c-Jun N-terminal Kinases (JNKs) is involved in the preventive effect of xanthorrhizol on cisplatin-induced hepatotoxicity. Archives of toxicology. 79(4):231-6.

Kaviarasan, S., Viswanathan, P. and Anuradha, C. V. (2007):

Fenugreek seed polyphenols inhibits ethanol induced collagen and lipid accumulation in rat liver. Cell. Biol. Toxicol.23(6):373-83.

Khorshidian, N., Mojtaba, Y.A., Masoumeh, A., Mirzaie, A.and Amir, M.M. (2016):

Fenugreek: potential applications as a functional food and nutraceutical. Nutrition and Food Sciences Research. 3(1):5-16.

Konopelnyuk, V., Kot, L., Makai, S. andOstapchenko, L. (2015):

Effect of Trigonella Foenum-Graecum seed powder on anthropometrical and nutritional parameter. Journal of Applied Pharmaceutical Science, (2015) 5 (11): 95-100.

Li, W., Yan, M.H., Liu,Y. Liu, Z. Wang , Z. Chen, C. Zhang, J. Sun, Y.S. (2016):

Ginsenoside Rg5 Ameliorates Cisplatin-Induced Nephrotoxicity in Mice through Inhibition of Inflammation, Oxidative Stress, and Apoptosis Nutrients, 8(9): 566.

Lu, Y. and Cederbaum, A.I. (2006):

Cisplatin-induced hepatotoxicity is enhanced by elevated expression of cytochrome P450 2E1. Toxicological sciences: an official journal of the Society of Toxicology. 89(2):515-23.

Mathern, J.R., Raatz, S.K., Thomas, W. and Slavin, J.L. (2009):

Effect of fenugreek fiber on satiety, blood glucose and insulin response and energy intake in obese subjects.Phytother Res.; 23(11):1543-1548.

Meera, R., Devi, P., Kameswari, B., Madhumitha, B. \& Merlin, N.J. (2009):

Antioxidant and hepatoprotective activities of Ocimumbasilicum Linn.andTrigonellafoenumgraecum Linn. against $\mathrm{H} 2 \mathrm{O} 2$ and CCL4 induced hepatotoxicity in goat liver. Indian J. Exp. Biol., 47: P.584-90.

Meghwal, M. and Goswami, T.K. (2012):

A Review on the functional properties, nutritional content, medicinal utilization and potential application of fenugreek.J Food Process Technol; 3(9).

Mehrafarin, A., Qaderi, A., Rezazadeh, S., Naghdi-Badi, H., Noor, G. (2010):

Bioengineering of important secondary metabolites and metabolic pathways in fenugreek (Trigonellafoenum-graecum L.). J. Med. Plants; 9(35):1-18.

Misra, H.P. and Fridovich, I. (1972):

The role of superoxide anion in the autoxidation of epinephrine and a simple assay for superoxide dismutase. J Biol Chem. 247(10):3170-5.

Mullaicharam, A., Geetali, D. and Uma, M. (2013): 


\section{Wesam M. Abd-EIrahman}

Medicinal values of fenugreek - A Review. Research Journal of Pharmaceutical, Biological and Chemical Sciences; 4(1):1304-1313.

Pratibha, R., Sameer, R., Rataboli,P.V., Bhiwgade, D.A. and Dhume, C.Y. (2006):

Enzymatic studies of cisplatin induced oxidative stress in hepatic tissue of rats. European journal of pharmacology. 532(3):290-3.

Raju, J. and Bird, R. P. (2006):

Alleviation of hepatic steatosis accompanied by modulation of plasma and liver TNF-alpha level by Trigonella Foenum graecum seeds in zucker obese (Fa/Fa) rats. Int. J. Obes, 30 (8): 1298.

Raju, J., Patlolla, J.M., Swamy, M.V. and Rao, C.V. (2004):

Diosgenin, a steroid saponin of Trigonella foenum graecum (Fenugreek), inhibits azoxymethane-induced aberrant crypt foci formation in F344 rats and induces apoptosis in HT-29 human colon cancer cells. Cancer EpidemiolBiomarkers Prev., 13 (8): 1392.

Reeves, P.G., Rossow, K.L. and Lindlauf, J. (1993):

Development and testing of the AIN-93 purified diets for rodents: results on growth, kidney calcification and bone mineralization in rats and mice. J. Nutr. 123: 1923-1931.

Saad, S. Y., Najjar, T. A. and Alashari, M. (2004):

Role of non-selective adenosine receptor blockade and phosphodiesterase inhibition in cisplatin-induced nephrogonadal toxicity in rats.Clin. Exp. Pharmacol Physiol. 31: 862-867.

Siddik, Z.H. (2003):

Cisplatin: mode of cytotoxic action and molecular basis of resistance. Oncogene. (47):72657279 .

Sinha, A. K. (1972):

Colorimetric assay of catalase, Analytical Biochemistry, 47:2:389-394.

Sonnenwirth, A. and Jaret, L. (1980):

Grad Wholes Clinical Laboratory Methods and Diagnosis. 18 ed Mosby, London, pp: 258-259.

Srinivasan, K. (2005):

Plant foods in the management of diabetes mellitus: spices as beneficial antidiabetic food adjuncts. International J. FoodSciences and Nutrition, 56 (6): 399.

Tarola, A.M., van de Velde, F., Salvagni, L. and Pretti, R. (2013):

Determination of phenolic compounds in strawberries (Fragariaananassa Duch) by high performance liquid chromatography with diode array detection. Food Anal.Methods. 6:227237.

Tsuruya, K., Ninomiya, T., Tokumoto, M., Hirakawa, M., Masutani, K.and Taniguchi, M. (2003):

Direct involvement of the receptor-mediated apoptotic pathways in cisplatin-induced renal tubular cell death.Kidney international. 63(1):72-82.

Uchiyama, M. and Mihara, M. (1978): 
Determination of malonaldehyde precursor in tissues by thiobarbituric acid test.AnalBiochem., 86: 271-8.

Wang, D. and Stephen , J.L. (2005):

Nature reviews Drug discovery. 4(4): 307-320.

Wang ,G., Reed, E. and Li, Q. (2004):

Molecular basis of cellular response to cisplatin chemotherapy in non-small cell lung cancer.Oncol.Rep. 12: 955-965.

Yogesh, C.Y.,Srivastav, D.N., Seth, A.K. andSaini, V. ( 2010):

Nephroprotective and curative activity of LepidiumsativumL. seeds in albino rats using cisplatin induced acute renal failure. Scholars Research Library Der PharmaChemica, 2 (4): 57-64.

Zicca, A.Cafaggi , S., Mariggio, M. A., Vannozzi, M.O., Ottone, M., Bocchini, V., Caviglioli, G. and Viale, M., (2002):

Reduction of cisplatin hepatotoxicity by procainamide hydrochloride in rats.Eur J. Pharmacol. 442:265-272.

التأثير العلاجي والوقائي لبذور الحلبة على تلف الكبد التأكسدى الناجم عن السيزبلاتين 


\section{في ذكور الجرذان}

\section{وسام كحم عبد الرحمن}

قسم التغذية و علوم الأطعمة, كلية الإقتصاد المنزلي, جامعة الأزهر

$$
\text { المستخلص العربى }
$$

الحلبة من النباتات العشبية الطبية الثائع استخدام اور اقها وبذور ها كطعام أوكشراب وقد أجريت هذه الدراسة لمعرفة تأثير مسحوق بذور

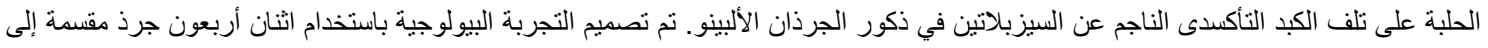

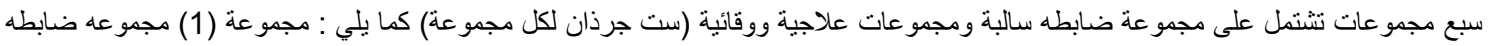

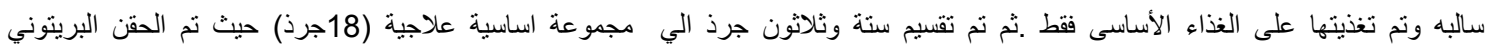

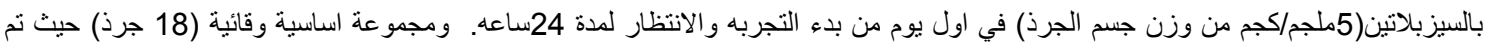
الحقن البريتوني بالسيزبلاتين في اخر يوم من انتهاء التجربه بجرعة (5ملجم/كجم من وزن جسم الجرذ) و الانتظار لمدة 24 ساعة .

المجموعة العلاجية عبارة عن ثلاث مجموعات فرعيه وهي: المجموعة الفرعية (2) مجموعه ضابطه موجبه علاجية حيث تغذت علي الغذاء

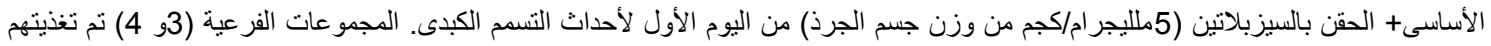

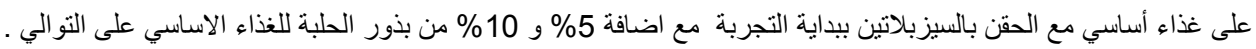

المجمو عات الوقائيه تشتمل ايضا علي ثلاث مجموعات وهي كالتالي: المجموعة الفرعية (5) مجموعه ضابطه وقائية موجبه تخذت علي

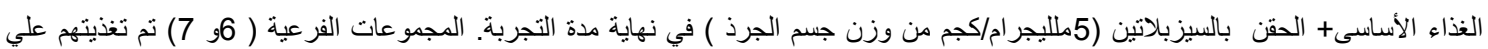
الغذاء الاساسي + التدعيم ب5٪ و 10\% من بذور الحلبة علي التو الي+ الحقن بالسيزبلاتين في نهاية التجربة.

فى نهاية التجربه البيولوجيه تم تصويم الجرذان طوال الليل (12 ساعه) وذبحها وأخذ عينات الدم من الأورطى لعمل التحاليل الكميائيه

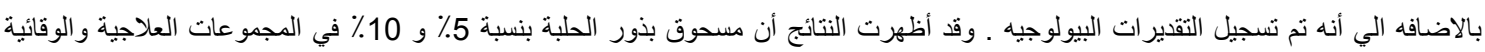

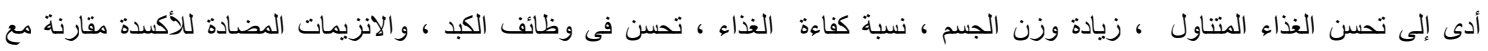

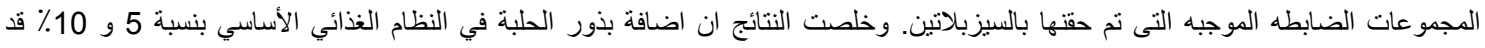

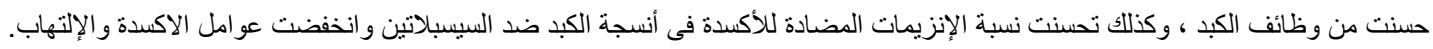

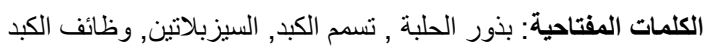

